\title{
Tumor Suppressor Gene
}

National Cancer Institute

\section{Source}

National Cancer Institute. Tumor Suppressor Gene. NCI Thesaurus. Code C17362.

Tumor Suppressor Genes encode proteins whose functions inhibit expression of

tumorigenic phenotypes by holding cellular proliferation in check. When inactivated or lost, a barrier to normal proliferation is removed and deregulated growth is possible.

$(\mathrm{NCl})$ 